\title{
Kłaniając się okolicznościom
}

Marek Zaleski

TEKSTY DRUGIE 2020, NR 5, S. 379-398

DOI: 10.18318/td.2020.5.23 | ORCID: 0000-0002-9418-4095

To takie anachroniczne mówić coś do druku. Wiersz czasownikowy

$\mathbf{P}$ oezja Sommera poezją okolicznościową?' Coś jest na rzeczy: w jego wierszach mamy do czynienia z natłokiem rozmaitych odniesień; tak! - referencja pcha się wszystkimi porami do lirycznej monady Sommera, więc Sommer żadną monadą zgoła nie jest! Znajdujemy mnóstwo odwołań do zdarzeń, miejsc, do przywołanych z imienia przyjaciół i znajomych. A jednocześnie Sommer w ułożonych przez siebie wyborach własnych tekstów - myślę o zbiorach Rano na ziemi i Po ciemku też - sięga po takie wiersze dość wstrzemięźliwie. Czy dlatego, że uznał, iż poezję, która ucieka od okoliczności i skupia się na nieobliczalności językowego gestu, czeka podwójna

\author{
Marek Zaleski \\ - profesor nauk \\ humanistycznych \\ w Instytucie Badań \\ Literackich PAN, \\ kierownik Zespołu \\ do Badań nad Litera- \\ turą i Kulturą Późnej \\ Nowoczesności. \\ Ostatnio opubliko- \\ wał zredagowaną \\ wraz z Adamem \\ Lipszycem książkę \\ zbiorową Ciała zdru- \\ zgotane, ciała oporne. \\ Lektury afektywne XX \\ wieku (2015). Kontakt: \\ marek.zaleski@ibl. \\ waw.pl
}

1 Tekst pochodzi z konferencji „Ulubione kawałki. Piotr Sommer: poezja - krytyka - przekład", zorganizowanej przez Instytut Filologii Polskiej Uniwersytetu Wrocławskiego w dniach 20-21.03.2019.

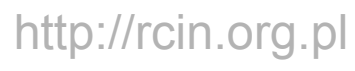


wygrana: uniknie zarówno ciężaru rzeczywistości jak i nieznośnej lekkości światowości? Kiedy Sommer zaczął pisać wiersze, wiedza, że rzeczywistość w nich istnieje niczym mleko w naszej nowej maszynce do spieniania mleka, była już komunałem. O doświadczaniu jakich okoliczności może być mowa w języku tak przyrządzonym? Jakkolwiek nie tych przywołanych wprost po imieniu, to jednak ciągle pozostających przygodą piszących i czytających ciał. Więc choć redaktorskie oko Sommera odsiewało natłok okolicznościowych referencji, to i tak zjawiały się w jego wierszach, i jak już, to hałaśliwie. W końcu Erraty wybrane, tomik, w którym znalazły się spychane w cień a dopominające się o swoje uznanie Sommerowskie paralipomena: pastisze, parodie, żarty i utyskiwania, cały ten bric-à-brac, który on sam tak lubi mieć na podorędziu, to - nie przymierzając - tłusty czwartek poezji okolicznościowej, orgia tekstualności zaplątanej w rozmaite porządki, które już dzisiaj zgłębia i zgłębiać będzie, grono badaczy twórczości Piotra Sommera. Zgoda (i szkoda!) - autor folguje swoim pasjom zgoła pokątnie: Erraty wybrane ukazały się w nakładzie 44 numerowanych egzemplarzy ${ }^{2}$. Ale można je uznać za tę resztę (resztkę?), która wcale nie chce być - i nie jest - milczeniem, gdy chodzi o ustawianie poetyckiego głosu autora Dni i nocy. Bo też i kategoria "okolicznościowego" długo postponowana w dyskursie na temat poezji nowoczesnej zasługuje na rehabilitację i na ponowne rozważenie. W końcu jeden z najważniejszych dziś - i nie tylko dla Sommera - poetów, czyli Frank O’Hara, uchodzi za autora poezji „okolicznościowej” właśnie. Czy coś w tym nienormalnego? Czy poezja nie kłania się okolicznościom jak długo istnieje? Jak pamiętamy, Goethe $\mathrm{w}$ Rozmowach z Eckermannem powiedział, że wszystkie jego wiersze są inspirowane rzeczywistymi zdarzeniami i mają charakter okolicznościowy, a poezja okolicznościowa ma wartość najwyższą. Wtórował mu Hegel, który doceniał poetycką doraźność manifestującą się w wierszach okolicznościowych, niesłusznie - jego zdaniem - uważanych za podrzędne, ponieważ pozostających w zależności od czegoś, co ulokowane na zewnątrz poetyckiej reprezentacji, bo jak podkreślał, wynikiem tej zależności są często najsłynniejsze utwory poetyckie ${ }^{3}$. Jeśli wywołuję tu „okolicznościowy” charakter poezji Sommera, to jest w tym prowokacja i głębszy zamysł. W wydobywaniu okolicznościowego wymiaru wypowiedzi poetyckiej o wiele istotniejszy wydaje się inny trop: mianowicie ten, który kulminuje w dzisiejszym myśleniu o charakterze

2 We wrocławskim wydawnictwie Pomona w roku 1997.

3 Por. G.W.F. Hegel Wykłady o estetyce, przeł. A. Landman, J. Gołębiowski, PWN, Warszawa 1967, t. 3, s. 324 . 
języka poetyckiego. Jak w filozoficznym skrócie Heglowski aforyzm o czytaniu porannej gazety zastępującym nowoczesnemu człowiekowi modlitwę ilustruje sposób, w jaki Zeitgeist objawia się, nie naruszając przy tym codziennej rutyny, tak - zdaniem Agambena - dokonany przez Emile'a Benveniste'a opis wypowiedzi jako użycia języka wydobywa wydarzeniowość języka mającą zawsze charakter okolicznościowy ${ }^{4}$. Chodzi więc o naturalną, przyrodzoną wypowiedzi (w tym wypowiedzi poetyckiej) właściwość, dlatego dalej nie opatruję tego pojęcia cudzysłowem odsyłającym wprost do klasyfikacji gatunkowej bądź nadającym mu (jak w tytule mojego tekstu chociażby) modalność ironicznego dystansu (to zamierzona prowokacja).

Przypomnę: zdaniem filozofa owa wydarzeniowość manifestuje się na dwa sposoby. Po pierwsze, jako konkretny akt mowy, który ma to do siebie, że jest nieprzewidywalny, indywidualny i zależny od okoliczności. Agamben podkreśla, że Benveniste pokazał, iż zaocznie i w sposób uprzedni nie sposób ustalić reguł przesądzających o tym, jak dokonuje się przejście od znaku (słowa) do zdania: „nie można przewidzieć ani zrozumieć w jaki sposób i za sprawą jakich operacji znaki zostaną wykorzystane do zbudowania pewnej wypowiedzi" (A, 118). Wypowiedź jest rezultatem operacji na słowach, która - choć kodyfikowana przez reguły języka - zawsze zostawia pole wolności czyjemuś działaniu pośród okoliczności i okazuje się efektem konkretnych aktów mowy dokonywanych w sytuacjach, w których zarazem owe reguły są aktualizowane. Czyjaś wypowiedź to „sposób istnienia” poprzez „dzianie się mowy” "w „zewnętrzu mowy” (A, 141). Utrwalona w formie drukowanej stanowi zapis, partyturę przyczajonej potencjalności znaczeń. Obecne w wypowiedzi zaimki wskazujące: ,ja”, ,ty”, ,to”, ,teraz”, „tutaj”, ,wtedy” itd., czyli shiftery, w odróżnieniu od innych słów, nie mają znaczenia leksykalnego i nabierają swoich znaczeń jedynie przez odniesienie do konkretnego aktu mowy, w którym zostaną użyte (A, 119). I tak np., ,ja" można zdefiniować jedynie w kategoriach lokucyjnych, a nie w kategoriach obiektywnych - do tej ostatniej sytuacji dochodzi w przypadku rzeczowników jako nazw własnych i pospolitych. "Ja" oznacza osobę wypowiadającą się w konkretnym akcie mowy. Jaki status ma więc wypowiedź i do czego się odnosi? „Wypowiedzenie nie odnosi się zatem do tekstu wypowiedzi, lecz do swego aktu, swojego konkretnego dziania się, [gdzie ktoś - przyp. M.Z.] może posłużyć się językiem pod warunkiem, że rozpozna się w samym wydarzeniu mówienia" (A, 119).

4 G. Agamben Co zostaje z Auschwitz. Archiwum i świadek. Homo sacer III, przeł. S. Królak, Sic!, Warszawa, 2008, s. 118. Dalej cytaty z tej rozprawy opisuję jako A, z podaniem numeru strony. 
Wydarzeniowość mówienia okazuje się kategorią nadrzędną, określającą charakter wypowiedzi.

Po drugie, wydarzeniowość języka manifestuje się, oczywiście, jako sprawczość aktu mowy. I tu także wypowiedź to „sposób istnienia” w świecie użyć języka. W przypadku wypowiedzi poetyckiej jej performatywny charakter realizuje się jako autoreferencjalność. Poezja jest użyciem języka, które samo siebie obiera za swój przedmiot odniesienia, odsyłając do tej rzeczywistości, którą ustanawia. Wskazując na rzeczywistość, którą zarazem ustanawia, jest „czystym samo-odnoszeniem się języka w konkretnym akcie mowy” (A, 139). Zastępuje relacją samozwrotności relację słów i rzeczy ustanawianą [w innych typach wypowiedzi - przyp. M.Z.] jako denotacja ${ }^{5}$. Nie chodzi więc o to, czy słowa opisują (prawdziwie) rzeczywistość, ale - jak Agamben powiada - chodzi o „czystą formę relacji pomiędzy mową a światem, która [za sprawą poetyckiej składni - przyp. M.Z] sama teraz zaczyna tworzyć więzi i tworzyć rzeczywiste skutki"6. W przypadku wypowiedzi poetyckiej język „zawiesza swój denotacyjny tryb działania” po to, by uzasadnić owe ustanawiane w tekście „związki z rzeczami"7.

Podsumujmy zatem. O znaczeniu wypowiedzi decydują sytuacje, w jakich dokonują się wypowiedzi określające jej użycie. W przypadku wypowiedzi, którą okoliczności kwalifikują jako poetyckie użycie języka, język przegląda się w swoich użyciach niczym w lustrze - i z takim jego wcieleniem dane jest nam obcować. Poeta, chcąc nie chcąc, pozostaje zakładnikiem spektaklu okoliczności, niezależnie od tego, czy jest kapłanem czy tylko ministrantem, pokornym sługą „Jego Rozwiązłości” - języka, by uciec się do sformułowania samego Sommera. Udany wiersz okazuje się szczególnie fortunnym zbiegiem okoliczności.

Owo stawanie się wypowiedzi jako zdarzenia będącego „wpisywaniem mowy w świat" (A, 125), staje się dla mnie ważne, kiedy myślę o wierszach Sommera (ale przecież i o wierszach innych poetów). Kiedy myślę o nich jako fortunnych zbiegach okoliczności, o wydarzeniach mowy szczególnie znaczących dla mnie jako czytelnika. Odnoszę wrażenie, że zmiana, jaka dziś dokonuje się w naszym obcowaniu z poezją, polega na przywiązywaniu uwagi do zdarzeniowości jako modusu ustanawiania się znaczeń. A nawet na

5 G. Agamben Czas który zostaje. Komentarz do Listu do Rzymian, przeł. S. Królak, Sic!, Warszawa 2009, s. 155.

6 Tamże, s. 156.

7 Tamże. 
potęgowaniu owej zdarzeniowości. Sommer w swojej poezji był heroldem tej zmiany.

„To takie anachroniczne mówić coś do druku” - zauważa ironicznie Sommer i jest w tym jakiś triumf prekursora, a zarazem komunikat o wyborze własnej tradycji. Zauważmy bowiem: realizująca się poprzez wiersz wydarzeniowość (i zarazem zdarzeniowość w nim zapisana) jest potencjalnością, która zawsze przebywa w tekście (vide Benveniste), ale do niedawna była obecna w nim na sposób niejako utajony, wykrywalna w postępowaniu badacza poezji, dziś natomiast bywa także doświadczana na nowy sposób. Dotychczasowy prymat graficznie utrwalonego tekstu był - i jest - tylko historycznie zrealizowaną okolicznością właśnie; okolicznością, która eksponuje intelektualny i zarazem „literacki” wymiar wiersza. Ten jego intelektualny i literacki wymiar - jak dobrze wiemy - nie był jednak w historii poezji regułą i dla wielu dzisiaj wcale nie wydaje się najważniejszy. Wynalazek druku, potem wynalazek maszyny do pisania, a wreszcie komputera jako edytora tekstu przesądził o tym, że obcujemy z wierszem w cichym, wzrokowym czytaniu. Za sprawą tych wynalazków twory kultury jako formy znaczeniowe stały się wzrokocentryczne. Jak powiada Michael Lindt, maszyna do pisania pozwoliła pisarzowi zobaczyć, jak będzie wyglądał jego wiersz na stronie, i tym samym przyczyniła się do powstania wolnego wiersza ${ }^{8}$. Pozwoliła opanować wiersz wzrokiem, zobaczyć to, co wcześniej było zapamiętywane jako słyszane (zrytmizowane i zrymowane, skojarzone przez dźwięk, niezależny od składni i znaczenia). Większość wierszy nowoczesnych istnieje dla nas tylko w oku i dla oka. Ekran kartki pozwala je zidentyfikować jako wiersze właśnie, czyniąc znaczącymi delimitacje zdań i ich składnię. Są one widzialne dla oka, niesłyszalne dla ucha. Ich grafia przesądza o tym, czym są: zapisane jako proza zostałyby potraktowane jako rodzaj zdefektowanego tekstu (inaczej niż wiersz regularny, który zapisany prozą ciągle za sprawą metrum zachowuje swój poetycki charakter). Ale dzisiaj, coraz częściej oglądamy nagrania video, na których wiersze są czytane bądź wygłaszane. Gdy są czytane na głos, poprzez sygnały intonacyjne wydobyta zostaje rola składni oraz funkcje poszczególnych słów jako niekonwencjonalnie wykorzystanych elementów zdania, akcentowane są przerzutnie w nieoczekiwanych wygłosach (enjabements). W kulturze audiowizualnej nazywanej dziś post-print oral and aural

8 M. Lindt The Re-enchantment of poetry. Why Poetry should be heard, not seen, https://thesmartset.com/the-re-enchantment-of-poetry/ (03.03.2019). Dalej w tym akapicie referuję przedstawiony przez autora tok rozumowania w odniesieniu do ewolucji form obcowania z poezją. 
culture - utrzymuje Lindt - powracają niegdysiejsze miary metryczne, miary Homera, bardów nordyckich sag. Już powróciły w formie rapu. I okazuje się, że poezja niczym pieśń i taniec jest doświadczana jako performans, i dzięki temu uznawana za poezję właśnie. Z pewnością zaś nie jest już traktowana jedynie jako retorycznie odkształcony komunikat.

My, uczestnicy festiwali literackich, kiedy czytamy poetów, często również słyszymy ich w naszych głowach. Również Sommer przyzwyczaił nas do tego, że w niemej lekturze szukamy śladów jego głosu albo odwołujemy się do wykonań głosowych samego Sommera, do pamięci jego indywidualnej fonetyki. "O poezji z przyświstem" - tak zatytułował swój szkic o wierszach Sommera Adam Lipszyc ${ }^{9}$. Do niedawna „poezja w nierozerwalny sposób z związana $\mathrm{z}$ autorskim wykonaniem głosowym, uchodziła często za przekroczenie ram literatury, za przypadek graniczny lub osobny" - pisze Aleksandra Kremer ${ }^{10}$. I dalej: „W wersji wygłoszonej włączano ją zaś w pola performance'u, intermediów lub muzyki, dla literatury zostawiając jedynie partyturę", a więc traktowano ją jako dokument życia literackiego, coś przynależnego do archiwum kultury literackiej. Było więc tak, że materialne wykładniki tekstu mówionego, akcent, intonacja, tembr głosu uznawane były przez literaturoznawców (i nie tylko tych o proweniencji strukturalistycznej) za redundantne residua, jako niemalże „odchody znaczącego"11. Dziś w dobie cyfrowej audiowizualności coraz częstsze, a i coraz bardziej atrakcyjne okazuje się nasze obcowanie z autorskim wykonaniem wiersza - i coraz częstsze stają się inicjatywy badań poezji wykonywanej przez autorów, jak również powołujące do życia obieg literacki takich wykonań poezji. Kremer pisze o powstałej na Uniwersytecie Pensylwania inicjatywie Charlesa Bernsteina, który „zainicjował PennSound, internetowe archiwum nagrań poetyckich, a w roku 1998 zredagował książkę Close Listening, nawołującą do odejścia od monopolu uważnego czytania na rzecz uważnego słuchania"12. Omawia też w swoim artykule inne inicjatywy

9 A. Lipszyc 0 poezji z przyświstem. Pozycja głosu, uniwersum przedmiotów i ten za przeproszeniem, język w poezji Piotra Sommera, w: Wyrazy życia. Szkice o poezji Piotra Sommera, red. P. Śliwiński, Wydawnictwo Wojewódzkiej Biblioteki Poezji i Centrum Animacji Kultury w Poznaniu, Poznań 2010, s. 52-62. A. Kremer Głośna poezja, "Teksty Drugie” 2015 nr 5, s. 105.

Tę metaforę Mladena Dolara z jego książki A Voice and Nothing More przywołuję za Dominikiem Antonikiem z jego tekstu Audiobook: od brzmienia słów do głosu autora, "Teksty Drugie" 2015 nr 5, s. 136 .

Tamże, s. 108. 
badawcze podejmujące próby opisu „autorskich realizacji utworów i ich znaczenia w kulturze", za granicą i w Polsce. Od siebie dodam, że projektowi Bernsteina wiele uwagi poświęciła Marjorie Perloff'³. Coraz częściej również wydawcy zamieszczają na swoich stronach zapisy autorskiego czytania wierszy, a i YouTube dzisiaj bywa miejscem całkiem przyjaznym poezji.

Literaturoznawstwo przyznało wierszowi status tekstu utrwalonego w druku i czytanego w niemej lekturze, faworyzując tym samym wiersz jako wehikuł przemieszczanych znaczeń: tekstowego i retorycznego. We wzrokocentrycznej perspektywie tekst wymagał ponawiania lektury (jako będącej zabiegiem hermeneutycznym). Ale takie rozumienie tekstu nie musi być jedyne, a przede wszystkim nie musi stanowić jedynego wzorca obcowania z tekstem poetyckim. Za dowód niech posłuży tu pewien dialog. Literaturoznawcze standardy postępowania $\mathrm{z}$ tekstem zostały niewątpliwie w nim przekroczone, ale ilustruje on zmianę w postępowaniu z tekstem i oczekiwaniach wobec samej poezji, z jaką zaczynamy mieć do czynienia na gruncie post-print oral and aural culture:

Jim Jarmusch: Kenneth Koch dał mi kiedyś wiersz Rilkego, po niemiecku, i powiedział: „Jim, zjawiaj się u mnie za dwa dni z przetłumaczonym wierszem”. Ja na to, „ale ja wcale nie znam niemieckiego”. A on: „otóż to!”. Chciał, żebym z tym zrobił, co tylko zechcę. Ta sama ilość wersów, ale wiesz: żebym zrobił z tego nowy wiersz.

Jonas Mekas: To właśnie robił Zukofsky z poetami latynoamerykańskimi - tłumaczył ich ze słuchu. Tak samo robili Robert Kelly z Schuldtem. Wzięli wiersz Hölderlina i kierując się samym brzmieniem przetłumaczyli na angielski, a potem - to już było piąta woda po kisielu - w ten sam sposób przetłumaczyli go na niemiecki.

J.J.: Fantastyczne!

J.M.: I opublikowali to.

J.J.: Bardzo zabawne.

J.M.: Wszyscy mamy za sobą takie doświadczenia: nie znasz języka, ale słuchasz tekstu i zdaje ci się, że rozumiesz, ale w efekcie masz coś zupełnie innego. Ale co jest niesamowite, jak w tych przekładach Zukofsky'ego i w tym, co Kelly z Schuldtem zrobili z Hölderlinem - łapiesz coś z ducha tych wierszy, coś tam jednak zostaje.

13 Por. http://marjorieperloff.com/2009/12/16/close-listening/ (10.03. 2019). 
J.J.: To chyba E.E. Cummings powiedział,. „Możesz rozumieć wiersz nie wiedząc wcale co znaczy".

J.M.: Tak samo jest z filmem w języku, którego nie znasz: w jakiś dziwny sposób wiesz, co przeżywają bohaterowie i o czym mówią. ${ }^{14}$

Wiersz jest wydarzeniem i ta jego właściwość najbardziej do głosu dochodzi w głośnej, najlepiej autorskiej lekturze - wtedy sprawczość wypowiedzi jako gestu językowego unaocznia i „unausznia” się najpełniej. W cichej lekturze ten wymiar też pozostaje jakoś obecny, że przypomnę tu znane powiedzenie o tym, że lektura jest piknikiem, na który autor bądź autorka przynosi słowa, a czytelnik znaczenia, ale głośna, autorska lektura wiersza czyni go spektaklem nie wolnym od afektów; spektaklem w którym zaangażowane są zarówno umysły, jak i ciała jego uczestników. Według Roberta Pinsky'ego w głośnej lekturze słowa spadają na nas, atakując swym brzmieniem, zobowiązując nas i nakłaniając do czegoś - tę kauzalność odnajdujemy jego zdaniem w etymologii łacińskiej słowa occasio: imiesłów przymiotnikowy bierny occasus, occasum (od occidere - upadać, schodzić w dół) przywołuje znaczenie upadania i zarazem zbiegu okoliczności ${ }^{15}$.

Obecność autora okazuje się znacząca. Kiedy przystępujemy do lektury poety, którego poznaliśmy naocznie i „nausznie”, staje się on dla nas postacią i głosem - kimś, z kim potrafimy nawiązać empatyczną relację. Ten afektywny wymiar naszego doświadczenia pozostaje dla nas, jako czytelników, ważny. Choć adeptowi literaturoznawczej lingua franca wydać się może zamącającą lekturę i mylącą resztka, to jego obecność przesądza o intensywności poetyckiego gestu, gdzie werbalny wymiar wiersza, sam tekst, jest tylko nośnikiem afektywnego. Autor wślizguje się między tekst a odbiorcę. Słowa tekstu znajdują swoją akustyczną i mimiczną reprezentację, istnieją jako energia performatywnego zdarzenia, jakim jest wykonanie głosowe. A zatem przydechy, przyświsty, cedzenie słów, wszystkie te akcydensy stają się nagle ważną komponentą. Podobnie jak inne, nie mniej istotne w tym wszystkim środki wyrazu, które są zarazem wskazówkami użycia tekstu (i samej jego lektury): „czytaj jakbyś miał słuchać, nie rozumieć” (Piosenka pasterska). Albo: „[...] bo zawsze miło się rozmawia / o tym bezkarnym pomniejszaniu / odległości

14 Por. www.anothermag.com/design-living/9589/jonas-mekas-filmmaker-jim-jarmusch-director-interview (02.03.2019).

15 R. Pinsky Occasional poetry and poetry on occasions, "Paris Revue" 2000, Is. 154, www.theparisreview.org/poetry/734/occasional-poetry-and-poetry-on-occasions-robert-pinsky (03.03.2019). 
między brzmieniem a znaczeniem / prawda?..." (Dnii noce). Liczy się skracanie dystansu (a w ogóle - jak powiada Sommer - najlepszy jest „synchron" "Patrz, jak to się słyszy, / kiedy się mówi” czytamy w wierszu Synchron). Zatem owo skracanie dystansu ma głębokie uzasadnienie, skoro „w akcie mowy wypowiedzenie ujmuje nie to, co się mówi, lecz sam czysty fakt, że się mówi, z definicji ulotne wydarzenie mowy jako takiej” (A, 140). „Wpisanie mowy w świat” (A, 125) pozostaje zawsze przygodą. Pamiętamy: „Wypowiedzenie jest tym, co najbardziej jednostkowe, niepowtarzalne i konkretne, odnosi się bowiem do konkretnego aktu mowy, całkowicie wyjątkowego i niepowtarzalnego, a zarazem [gdy zaistnieje jako drukowane - przyp. M.Z.] jest tym, co najbardziej puste i ogólne, ponieważ [w każdej nowej lekturze - przyp. M.Z.] powtarza się za każdym razem [inaczej? - przyp. M.Z.] i nie sposób kiedykolwiek określić jego znaczenia leksykalnego [w sposób finalny - przyp. M.Z]" $(\mathrm{A}, 140)$. Świetną ilustracją tej konstatacji jest wiersz Niedyskrecje. Unaocznia, jak zabrudzone afektywnie znaczenie współistnieje z uniwersalnym:

Gdzie jesteśmy? W ironiach

których nikt nie chwyci, krótkotrwałych

i nieakcentowanych, w trywialnych pointach

które kwitują metafizykę niedorzecznym

detalem, w piątku co wypada,

na piątego listopada, w mnemotechnice dni.

Można dać przykład i można to przyjąć

na wiarę, kocią łapę na gardle.

I lubi się jeszcze pewne słowa, i te, za przeproszeniem, składnie, które udają, że coś je z sobą łączy.

W tych międzysensach zawiera się cały człowiek, włazi tam, gdzie widzi trochę miejsca.

Wypowiedź poetycka jako tekst mówiony, jako figuracja jej afektywnych komponentów jest bardziej zdarzeniem, aniżeli tylko enuncjacją podmiotu lirycznego albo grą słów, w której dyskontuje się figury retoryczne i organizację językowej wypowiedzi. W głośnym czytaniu ujawnia się eufonia albo zamierzona kakafonia, inkantacja, rytm, a więc czynniki które ustanawiają to, czym jest ten właśnie wiersz a co w tekstowej postaci istnieje jedynie potencjalnie albo śladowo. Tymczasem może stanowić jego siłę motoryczną. Głos Sommera w takiej głośnej lekturze nie jest głosem recytatora - to słowo 
należy do stylistycznie wysokiego rejestru, od którego on sam dystansuje się i który wykpiwa. Lepszym terminem byłoby spolszczone prawie sto lat temu przez Tytusa Czyżewskiego francuskie słowo entrepreneur będące określeniem przedsiębiorcy ${ }^{16}$; słowo, które w swoich historycznych użyciach zawierało aluzję do ponoszonego ryzyka i do awanturniczości poczynań kogoś, kto ekstrawagancko zarządza swoim kapitałem, tu: wizerunkiem poetyckim. Antreprener jako mistrz ceremonii, wodzirej z estrady na której polscy „futuryści" wyprawiali swoje brewerie. Wydaje się jakoś odpowiednie dla kogoś, kto odżegnuje się od gestów „dostojnych szamanów, którzy znali sekret” (to oczywiście Zbigniew Herbert w Liście do Ryszarda Krynickiego). Sommer nigdy nie ryzykuje swojej reputacji poetyckiej, przybierając pozę hierofanty. Albo, owszem, ryzykuje ją, ale sięgając po gest całkiem inny.

Słowo gest wydaje się słowem, przy którym warto się zatrzymać, bowiem jest z gruntu tym, co wydarzeniowe. Jak wiemy z teorii afektów, gest jest mową ciała, która może, ale wcale nie musi odpowiadać wypowiadanym słowom i ich znaczeniom. Gest językowy - więc gest metaforycznie rozumiany - podobnie. Ustanawianie znaczeń jest działaniem zmierzającym do celu, kieruje się intencjonalnością. Tymczasem - jak powiada Agamben - „Dla zrozumienia gestu nic nie jest bardziej mylne, niż wyobrażenie sobie najpierw sfery środków podporządkowanych celowi"17. Zdaniem filozofa gest zawiaduje tym, co w akcie ekspresji pozostaje nieoczywiste i nieostateczne albo niewyrażone. Liczą się tu np. przedsięwzięte środki, które koncentrują na sobie uwagę: „Gest jest czymś, co eksponuje medialność, czyni widzialnym środek jako taki”18. Wypowiedź poetycka zdaje się czynić coś podobnego. Jest mediacją: zostawia pole manewru autorowi, który dyskontuje retoryczne odkształcenie komunikatu. Staje się samozwrotna, zawiesza logikę wywodu, a nie tylko wspomaga ją, zmierzając najkrótszą drogą do celu. Zarazem autor jest kimś więcej niż personą liryczną. Jest on również - by odwołać się do zapomnianej dziś, a tu znowu na nowo użytecznej kategorii poetyki - podmiotem czynności twórczych. Jego „egzystencja rozgrywa się" w tekście, nie zaś tylko „wyraża się" czy „spełnia” ${ }^{9}$. Autor jest „obecny w tekście jedynie

16 Por. T. Czyżewski Włamywacz z lepszego towarzystwa (1922), w: tegoż Wiersze i utwory teatralne, słowo/obraz terytoria, Gdańsk 2009.

G. Agamben Notatki o geście, przeł. P. Mościcki, cyt. za: G. Agamben. Przewodnik Krytyki Politycznej, Wydawnictwo Krytyki Politycznej, Warszawa 2010, s. 301. 
jako gest” właśnie; gest, który „umożliwia ekspresję, ustanawiając w niej wyróżnioną pustkę", pustkę po nim samym jako autorze, jako że jego własny tekst wymazuje go albo sprowadza do jakiejś szczególnej postaci, „ucisza, tłumi, wykrzywia w grymas" ${ }^{20}$. To „puste” miejsce zajmuje czytelnik, który staje się świadkiem zachodzących w wierszu zdarzeń. Samo „wydarzenie wiersza”, powiada Agamben, sprowadza się do gestu manifestowania użytych środków, gestu „przez który autor i czytelnik rozgrywają się w tekście”21. Gest więc ustanawia pole mediacji, przestrzeń manewrową, w jakiej znajdują się autor, jego tekst i jego czytelnik. I wiele wierszy Sommera to takie terytoria manewrowe, by nie rzec, poligony słów:

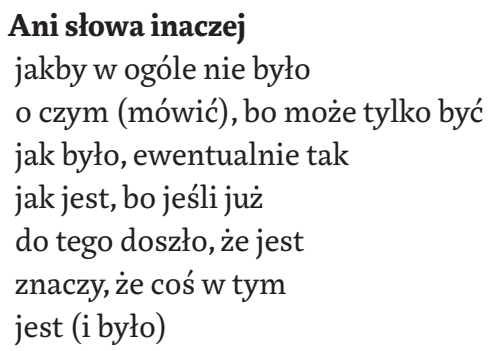

Ten wiersz każe się potraktować jako zaproszenie, by wejść na terytorium wydarzania się wypowiedzi, rozglądając się, co na nim daje się jeszcze zrobić. Podobnie jak Wiersz czasownikowy i sąsiadujący z nim Wiersz przymiotnikowy: w obu od biedy można próbować zaczepić się o jakąś anegdotę, ale przede wszystkim chodzi o dostrzeżenie, że pierwszy robią głównie czasowniki, a drugi przymiotniki. Takie traktowanie wiersza przesądza, że Sommer często nadaje tytuł ex post, niejako w rewizyjnej jego lekturze, i tytuł ustanawia ramę modalną poetyckiego komunikatu.

Wydaje się, że akurat w przypadku Sommera można powiedzieć, że wiersz stanowiący porte-parole autora jest gestem dopiero stwarzającym szansę wyprowadzania konkluzji z tego, co będąc przygodą przebywania pośród okoliczności mowy, podpowiada nieoczekiwane rozwiązanie albo je zawiesza. Niekiedy objawia się jako karambol, powstaje ze zderzenia rozmaitych, a i często obcych sobie porządków, jak w chwycie komediowym, domagając się niejako pointy: „Nie to, co chciałeś / ale to, co wyszło // (kochanie)”

\footnotetext{
20 Tamże, s. 84 .

21 Tamże, s. 90.
} 
(Tamto). Szczególnie dużo takich sytuacji mamy w Wierszach ze stów, które stanowią Sommerowe minima poetica, gdzie wyróżniony graficznie tytuł jest sam już częścią wiersza, albo pre-tekstem zderzonym z tekstem właściwym, bądź ironiczną preambułą:

Duch zrozumienia

Ale żeby tak w ogóle

Nie obchodzić siebie?

albo
Botanika
Matka mówiła do mnie z liścia
Ku memu zaskoczeniu
Po kilku latach.

albo

\author{
Nie jest jasne \\ w którą stronę cytujesz to zdanie.
}

Zastosowana tu (i w innych wierszach) jukstapozycja funkcjonuje podobnie jak gag komediowy będący zasadą budowania znaczeń, ale - w głośnej lekturze autora - nie tylko znaczeń: nieraz grymas autora wślizgującego się między tekst a czytelnika sugeruje, że znajdujemy się w świecie, którego ontologia rządzi się estetyką chwytu komediowego, czasami przyjaznego jak w wierszu Umowny, a czasami spotworniałego - jak w Nie śpij, notuj. Albo rządzi się nowszym wcieleniem estetyki buffo ${ }^{22}$. Tę predylekcję do tonu buffo wspomaga afektywna estetyka, w którą Sommer wpada, czytając: czyta, jakby tańcząc na cześć Jego Rozwiązłości języka, bawiąc się impetem swego mówienia. I ten gest jako poza najlepiej do głosu dochodzi w wierszach stricte okolicznościowych, takich jak Proza cienkiejJolki Paryżanki, Siostrzyczka, A więc to tak. To estetyka, która często odwołuje się do poetyki gagu. „Gag czyni śmieszną

22 Ta estetyka buffo, którą opisuje Sianne Ngai w swojej książce Our aesthetic categories: cute, zany, interesting (Harvard University Press, Cambridge, MA 2012) jako estetykę zany, to estetyka ustanawiania wątpliwych znaczeń. Zany tłumaczy się jako coś niedorzecznego albo - jak dziś mówimy - "odjazdowego", "zakręconego”, działania, które jest nazbyt hectic, czyli nazbyt gorączkowe, nadaktywne - także w procesie komunikowania się. 
sytuację, w której spotykają się dwie nieprzystające do siebie rzeczywistości, a ich współistnienie traktowane jest [...] jako coś naturalnego. Zderza się je więc ze sobą ukazując te ich aspekty, które w normalnym kontekście pozostają niezauważone. «Gag nie jest nonsensem ani czymś nielogicznym, tylko pozbawieniem sensu jednej logiki za pomocą drugiej; jego zaskakujący charakter nie jest rezultatem przedstawienia czegoś nieznanego, tylko spojrzenia pod nieoczekiwanym kątem na rzeczy znane; gag nie zaprzecza rzeczywistości, tylko analizuje ją do końca; nie odrzuca konwencji, lecz przeciwnie - opiera się na nich i z nimi współdziała»"23. Jak w makabresce, którą jest wiersz Nie śpij, notuj:

$$
\begin{aligned}
& \text { O czwartej nad ranem } \\
& \text { zastukała roznosicielka } \\
& \text { mleka w cywilu, grożąc } \\
& \text { że nam nic nie zostawi, } \\
& \text { zabierze najwyżej butelki, } \\
& \text { jeżeli nie okażę kwitu. }
\end{aligned}
$$

$$
\begin{aligned}
& \text { Kwit był w kubraku } \\
& \text { ale i tak wiedziałem } \\
& \text { jaki będzie dalszy ciąg: } \\
& \text { zabierze i wczorajsze, zsiadłe, } \\
& \text { zabierze ser i jajka, } \\
& \text { zabierze nam mieszkanie, } \\
& \text { zabierze nasze dziecko. } \\
& \text { Jeżeli nie okażę kwitu, } \\
& \text { jeśli nie znajdę kwitu, } \\
& \text { mleczarka podetnie nam gardło. }
\end{aligned}
$$

Zwykle gag ma charakter sytuacyjny, nieoczekiwany komizm pojawia się nagle, jest maleńką katastrofą zwykłego porządku albo nagłością odchylenia od rutyny, zabawą z językiem, posunięciem, które z deliberacją chybia celu, albo pokrewnym chaplinowskiej komedii istnieniem szlemielowskim. Z tą ostatnią odmianą komizmu w świecie Sommera mamy do czynienia dość

23 P. Mościcki Chaplin. Przewidywanie teraźniejszości, słowo/obraz-terytoria, Gdańsk 2018, s. 128. Tekst cytowany pochodzi z Anatomii gagu Václava Havla. 
często. Sommerowy szlemiel to trikster - ktoś, kto wyprowadza nas z tarapatów, okazuje się akcją pełną perypetii. Porusza się, naruszając obowiązujące porządki. Owo odchylenie czy też załamanie zapisane jest w gestach językowych podmiotu: a to jako żart, przejęzyczenie, złamanie uzusu językowego albo językowa nadaktywność wystawiająca na szwank językową odpowiedzialność mówiącego podmiotu. Czemu służy ten zabieg? Rzec by można, że zabawie jako w końcu nie najgorszemu sposobowi spędzania czasu, ale bywa i podstawieniem nogi komuś, kto w swoim zadufaniu sądzi, że skoro granice jego świata są granicami jego języka, to jego dezynwoltura językowa pozwala mu je przekraczać raz za razem. Ale w myśleniu o języku Sommer daleki jest od purytanizmu. Jeśli język może nas przejęzyczać i przedrzeźniać, to może nic nie jest przesądzone i przy tym warto się zatrzymać, uczynić przedmiotem żartu a co najmniej zastanowienia. Jak w wierszu, w którym Sommer opisuje przygodę swojego małego synka jako mimowolnego eksploratora języka. „Marcelu, nie kpij z Piotrka. / Ja nie kpiję, tylko pytam”, odpowiada strofowany przez mamę Marcel (Ciężki styczeń 1997). Tutaj Sommerowski gest szlemiela to także porozumiewawcze mrugnięcie do czytelnika: niestety, w końcu uczymy się mówić poprawnie, tak jak uczymy się robić dobre miny do nie zawsze dobrej gry.

Afektywna komponenta sytuacji, jaką jest wiersz, podważa wysuniętą przez Agambena tezę, że gest jest przede wszystkim mediacją: komunikuje gotowość zakomunikowania jakiejś treści, sam nie będąc żadnym komunikatem. Zresztą gdzie indziej w owej mediacji Agamben dopatruje się komizmu związanego z porozumiewawczą nadaktywnością, nieledwie krygowaniem się autora: najpierw zwraca się uwagę na coś mniej ważnego, odwleka i komplikuje to, co za chwilę zostanie oznajmione, a zaraz potem jakby przypomina się o tym, co ważne, albo zdradza się czytelnikowi sekret o trudności z jaką my - autor i jego czytelnik - mieliśmy do czynienia ${ }^{24}$. Sommer chętnie używa tego tonu - tonu głosu, który zdaje sprawę z zakłopotania autora, opatrywania

24 Tymczasem komizm jest kategorią estetyczną (więc dyskursywnie ustanawianą oceną) i zarazem komunikowanym doznaniem oraz stylistycznie zobiektywizowaną jakością, upostaciowaną w tekstowej reprezentacji. Komizm zatem - rozpoznany jako wyraz sądu estetycznego - jest obiektywizacją uczuć. Sąd estetyczny jako obiektywizacja uczuć ma to do siebie, że przynależy do klasy sądów performatywnie "kłopotliwych" - jak powiada Sianne Ngai we wspomnianej już książce - ponieważ jest sądem na poły opisowym, na poły zaś wartościującym i wyraża sposób, w jaki ktoś coś osądza, niby tylko opisując. Wartościowanie jest więc niejako przemycane, a obiektywizm sądu polega na maskowaniu jego subiektywności. Czyli na mediacji jako maskowaniu tych wszystkim zabiegów - taką mediację, zgoda, można uznać za coś komicznego. Ktoś oszukany zawsze jest trochę śmieszny. 
cudzysłowem stwierdzenia dopiero co zapisanego. To temu służą te wszystkie Sommerowe „opukiwania” własnych zdań, wszystkie te zastrzeżenia typu: „za przeproszeniem”, ,tej by tak rzec jesieni”, dopowiedzenia w rodzaju „i jeszcze mówi się...", wtrącenia, które zarazem jakby bagatelizują i pomniejszają ważność tego, o czym się mówi. Albo obniżające powagę makaronizmy bądź kolokwializmy, owe „zusammen i do kupy” i „pourquoi pas?”. Wreszcie pytania, jakimi Sommer lubi otwierać swoje wiersze, jakby dopuszczając nas do konfidencji po to, by „rozgrywać się” z nami w tekście, niczym przy stole ping-pongowym. Do konfidencji zaprawionej oczekiwaniem, że będziemy zdolni odkręcić piłeczkę - inaczej nie ma żadnej frajdy:

Ty sobą mi kochanie też czasami służysz, nie tylko tobie ja, bo kiedy normalnieje człowiekowi w pysku

język, może za przeproszeniem jest bardziej sobą? A może mnie, kto to wie w końcu - on sam, beze mnie, wiedziałby jeszcze mniej, prawda? Na przykład kiedy leżysz już, przed snem, a ja udaję złość

z powodu twoich nie zdjętych jeszcze okularów, ale ty nie wiesz, że udaję więc ja się szybko poprawiam i udaję wyraźniej.

Umowność, niepewność i ironia kogoś wystawionego na zbieg okoliczności, na mieszanie się rozmaitych porządków, w których żyjemy na co dzień wszystkie te rzeczy znajdują się u podłoża gestu, z którego Sommer uczynił znak firmowy swojej poezji. Jest to napięcie, jakie powstaje ze zderzenia patosu $\mathrm{z}$ batosem. Patos i batos to gesty obsadzone emocjonalnie: reprezentacje patosu to sygnatury podziwu, ale i przerażenia, choć zarazem zdolności oswajania tego, co nas przerasta bądź nam zagraża. W przypadku batosu mamy do czynienia z pomniejszeniem lub wręcz z deprecjacją. Batos neutralizuje lęk albo dramat konfrontowania się z czymś, co nas przekracza, jest antyklimaksem, obniżeniem 
tonu, subwersją wobec tego, co wysokie, co fałszywie pretenduje do chwały, narzędziem parodii lub trawestacji. Oczywiście, definicje patosu i batosu budowane są na podstawie sytuacji wyrazistych i zarazem typowych, więc i tutaj przywoływane przeze mnie formuły odnoszą się do doświadczania rzeczywistości in extremis albo in crudo. W przypadku poezji, która - jak to u Sommera instaluje się w codzienności, gdzie owe gesty są odpowiednio moderowane. Ale też przecież to, co nabiera pełnej wyrazistości w sytuacji wyjątkowej, przebywa potencjalnie w sytuacji pozornie normalnej i pozornie całkiem od tamtej odległej, jak choćby w cytowanym wierszu Nieśpij, notuj. Niekiedy jednak sytuacja zaprasza do tego, by nie przykręcać kurka z sarkazmem, zwłaszcza gdy to, co patetyczne, zostaje zderzone ze swoją karykaturalną realizacją:

Miejskie Przedsiębiorstwo Gospodarki Mieszkaniowej w Otwocku POZDRAWIA BRATNIE NARODY KRAJÓW SOCJALISTYCZNYCH

każdą z czterdziestu czterech liter umieszczonych na oddzielnych żerdziach,

tylko odstępy między wyrazami nie mają drzewców.

Jest jedenasty maja 1979 roku.

Drzewce wbite w trawnik tworzą falochron.

Miejskie Przedsiębiorstwo pozdrawia bratnie narody od ponad

Trzech tygodni,

Lecz one po dziś dzień nic o tym nie wiedzą

(Prowincja)

Patetyczne u Sommera okazuje się doświadczenie ulotnej gęstości codziennego życia i towarzysząca temu czułość dla pogrążonych w codziennej krzątaninie. O tym opowiadają wiersze, w których pojawiają się postaci z rodziny, przyjaciele, wreszcie on sam. Wiersze takie jak Światta dworca, Mały traktat o niesprzeczności, Kruchość czy Liść klonu albo Rano na ziemi przynoszą uczucie zanurzenia w toczącym się życiu, kojącą obecność ludzkiego kleju, niekiedy nawet pomyślenie, że czasem skądś prześwituje coś, co całą tę krzątaninę usensownia, a może nawet jakoś uświęca:

Rano na ziemi cienki śnieg, a przedtem

Tyle ciepła, prawie przedwiośnie.

Ale na termometrze w kuchennym oknie

plus siedem stopni

I w ogóle dużo słońca. 
Jest pan

od światła, którego lubię

i nie ma pana od gazu

którego nie cierpię.

I nagle dwaj panowie M. -

za jednym z nich przepadam, drugi

za bardzo prymus.

Wracają. Obaj dziewięcioletni.

Mijają krzak jaśminu, co jest

Jak duży bukiet z kresek.

Pod drzwiami

cieszy się pies, coś się z czymś

nie kłóci

(Rano na ziemi)

Towarzyszące temu uczucie - trudno go tak nie nazwać - wzniosłości wypowiedziane jest w języku całkiem zwyczajnym, tym „gadanym”. Język wydziela z siebie gadaninę - ją także. Prowokuje do zadawania pytań. Niekiedy pozwala na luksus nazywania. „Gadanie to moja specjalność, / ale naprawdę lubię słuchać, czyli pytać. / No i nazywać - / w jakiejś stosownej chwili" (Mogiłki). Poezja Sommera pozostaje z gadaniną w stosunku włączającego wyłączenia: nie przestając widzieć w niej gadaniny, dyskontuję ją jako coś, co stanowi matecznik językowego artefaktu. W końcu to tam właśnie „samo się mówi" (Higiena). Przyjemnie jest zanurzać oko w bezkresnym oceanie drukowanej mowy, ale dobrze jest też wejść w bezpośrednią interakcję z żywiołem mówionego, nawet jeśli miała by być ona z higieną na bakier, jak w wierszu Jego Rozwiązłość: „więc topiel / oka, a potem szybko: usta-usta”. Niezależnie, jakiego wyboru autor Dni i nocy dokona, zawsze dba o to, by dopuścić do głosu słowa z poluzowanego, chciałoby się powiedzieć, luzackiego słownika, jakby bojąc się nadmiernego patosu.

Często chęć przyjaznego uświetniania idzie w parze z żałobnym i bolesnym - jak w wierszu Konfirmacja, który z wiersza napisanego na urodziny syna przyjaciela zmienia się w żałobną, elegijną dirge, wywołując efekt znieswojenia. Owo napięcie czynne jest też w wierszach, które gęstość codziennego życia opisują jako jego dotkliwość, przywołując doświadczenie mozołu, utraty, choroby albo śmierci. Elegijne wiersze Sommera wpisują się w tradycję patetycznego użycia języka, ale - znowu: realizowane są często w obniżonym decorum językowym. Zatem patos i batos w wierszach Sommera 
często w jednym stoją domu za sprawą możliwości, jakimi dysponuje poetycka składnia. To ona zderza rzeczy niewspółmierne: urodę i dotkliwość życia, jego ciężar i jego komizm. Patos będący efektem tego zderzenia - doznania intensywnej gęstości, często męczącej i napawającej lękiem, ale także i będącej źródłem rozmaitych olśnień bądź przyjemności (jak w wierszu Habeas ossa) - sprawia, że niekiedy wiersze Sommera stają się parabolami zepchniętymi ze swego parabolicznego toru przez żart - w tym akurat wierszu: tytuł. Psychoanaliza nauczyła nas, że żart jest dobrym epitafium dla trudnych do opanowania emocji.

Najważniejsze dla mnie jako czytelnika Sommera pozostaje jednak to, że sam autor jako gest, jako sprawca wydarzenia się wiersza, pozostaje w mojej lekturze tak silnie obecny. Wiersze Sommera należą z góry do tych „pisanych na głos", by uciec się do formuły Rolanda Barthes'a ${ }^{25}$, co skutkuje wrażeniem jakie towarzyszy mojej lekturze Sommera nałożonej na obraz Sommera czytającego Sommera. I nie ma żadnego dobrego powodu, by miało być inaczej. Głos, jak powiadają psychoanalitycy - idiomatyczny i niepowtarzalny uwodzicielski obiekt a - wytwarza intymną relację słuchacza i mówiącego ${ }^{26}$. Nie przypadkiem przecież: jak podkreślał Benveniste, „ja” oznacza osobę wypowiadającą ,ja” w konkretnym akcie mowy, głos jest więc wehikułem jej podmiotowości ${ }^{27}$. Nawet w swojej niemej lekturze mam ochotę wyobrażać sobie jak wiersz Sommera mógłby zostać nam przez niego przeczytany czy wręcz odegrany, wraz z czynną w tym wszystkim mowę ciała, nie mówiąc oczywiście o najważniejszej komponencie: o pracy samego głosu, o jego modulacji i artykulacji. W wierszu Korekta autor nie omieszka przypomnieć, że ważny jest „rytm zdania, myślenia, języka”. Rytm, jak o tym pisze w swym projekcie krytyki somatycznej Adam Dziadek, jest zorganizowaną energią mówiącego ciała. Nie musi wcale zbiegać się z istnieniem metrum: jest nieprzewidywalny, idiomatyczny i musi być postrzegany jako „zespół, poprzez który signifiants językowe i pozajęzykowe wytwarzają specyficzną, różną od

25 R. Barthes Przyjemność tekstu, przeł. A. Lewańska, KR, Warszawa 1993, s .97-98.

26 Por. Gaze and voice as love objects, ed. by R. Salecl, S. Žižek, Duke University Press, DurhamLondon 1996.

27 Zapewniając podmiotowości jej materialną podstawę, głos jako fundament wypowiedzi jest paradoksalnie także wehikułem odpodmiotowienia: pozostaje niezależny od znaczenia wypowiedzi, istnieje od niej niezależnie, ale jako nośnik wypowiedzi jest współodpowiedzialny za dokonujące się w wypowiedzi (poprzez język) odpodmiotowienie mówiącego (por. G. Agamben Co zostaje z Auschwitz..., s. 114-120). 
sensu leksykalnego semantykę (signifiance - znaczącość, która staje się wtórną, suplementarną wartością wypowiedzi). Cechy te mogą być rozmieszczone na wszystkim poziomach wypowiedzi: akcentowych, prozodycznych, leksykalnych, syntaktycznych (rozkładają się one w tekście niczym temat w opowiadaniu).W ten sposób signifiants są zarówno syntaktyczne, jak i prozodyczne. Sens nie jest już zawarty leksykalnie w samych słowach"28.

Wszystko to sprawia, że czytając, mimowolnie ustanawiam sobie obecność autora. Kiedy mam do czynienia z jego autorską lekturą, mam do czynienia $\mathrm{z}$ materialną inscenizacją aktu poetyckiego, z mise-en-scène aktu mowy. Owo mise-en-scène ma swoją topografię. Wszystko przecież rozgrywa się w jakiejś przestrzeni: wygląd poety, ton głosu i rodzaj dykcji, przynależne rekwizyty czy obecna w tym wszystkim jakaś dekoracja, rodzaj oświetlenia, obecność uczestników spotkania poetyckiego, wszystko to staje się znaczące. Stanowi komponentę teatralnej dramaturgii, współczynną w inscenizowaniu podmiotowości czytającego autora ${ }^{29}$. Owo mise-en-scène jest, jak powiada Bal, „materializacją, tekstu w formie dostępnej publicznemu, zbiorowemu odbiorowi, mediacją między sztuką a złożoną publicznością, [...] i każdą jednostką wchodzącą w jej skład"30. We flashbackach pamięci bywalca wieczorów literackich okazuje się tworzywem obrazu poetyckiego. Nie mogę więc wyprzeć się, że kiedy czytam Sommera, czytam go tak, jakbym widział go czytającego czytany przeze mnie tekst jego wiersza. Może zresztą w przypadku autorów współczesnych, tych, których choć raz widzieliśmy czytających swoje wiersze, nigdy nie czytamy inaczej. Więc w mojej samotniczo dokonywanej niemej lekturze mise-en-scène zmienia się w mise-en-page. W czytelniczym doświadczeniu przez płaską powierzchnię tekstu prześwitują powidoki żywej materialnej obecności autora, wspomnienie głębi, z jaką jego obraz narzucał się mojej wrażliwości i percepcji. Nie będzie chyba błędem stwierdzenie, że aura jakiej przydaje tekstowi sygnatura autorska jest w istocie niczym innym, jak scaloną w nazwisku autora esencją rozmaitych przygodnych i zarazem historycznych mise-en-scènes przekazanych potem $\mathrm{w}$ rozmaitych relacjach potomności (relacjach rozmaitego charakteru, nie wyłączając opracowań historycznoliterackich czy interpretacji literaturoznawczych). Okoliczności są zatem ważne: nawet kiedy istnieją już zakrzepłe w postaci naszej literaturoznawczej

28 A. Dziadek Projekt krytyki somatycznej, Wydawnictwo IBL PAN, Warszawa 2014, s. 22. trum Kultury, Warszawa 2012 (zwł. rozdz. "Mise-en-scène”, s. 125-159). 
wiedzy, w postaci zapadłych w naszą pamięć ukształtowanych obrazów autora czy figur jego języka, w ponowionej lekturze wiersza ich czysto intelektualny charakter zyskuje wymiar afektywny i nieodłącznie związany z autorem, który uplątał nas w teatr gestów. Zatem zadrukowana kartka papieru z tekstem Sommera zawsze będzie miejscem pełnym Sommera. Jest właśnie tak: „cały człowiek włazi tam, gdzie widzi trochę miejsca".

\section{Abstract}

\section{Marek Zaleski}

THE INSTITUTE OF LITERARY RESEARCH OF THE POLISH ACADEMY OF SCIENCES (WARSAW) Bowing to Circumstances

In his poetry Piotr Sommer often makes circumstantial references to events, places, friends and acquaintances whom he mentions by name. For Zaleski this is a pretext for reviewing the classification of what is "occasional" in poetry. He describes the poetic statement in today's post-print oral and aural culture, which resuscitates the old tradition of uses of poetry - a tradition that is now being relearned. Zaleski describes Sommer's poetic gestures and explores how Sommer's reading of poems determines their reception: live reading as a performance codifies eventality, allows us to realise that a poetic statement refers to its act, to its concrete happening and only then, in consequence, to the text of the poem.

\section{Keywords}

poetry, gesture, post-print oral and aural culture, mise-en-scène, mise-en-page 